International Journal of Engineering \& Technology, $7(4.36)(2018) 424-428$
International Journal of Engineering \& Technology
SPC
Website www.sciencepubco.com/index.php/IJET
Research paper

\title{
Effect of Urease Enzyme on Shear Strength of Clay Shale
}

\author{
${ }^{[1]}$ Maxwel Joseph Henri Nainggolan, ${ }^{[2]}$ Wiwik Rahayu*, ${ }^{[3]}$ Puspita Lisdiyanti \\ ${ }^{[1]}$ Graduate Student, Department of Civil Engineering, Universitas Indonesia, Indonesia \\ ${ }^{[2]}$ Department of Civil Engineering Universitas Indonesia, Indonesia
}

\begin{abstract}
In recent years, utilization of biotechnology in geotechnical field has rapidly grown. One of the biotechnologies being utilized is urease enzyme, a stabilization material by bio-cementation method studied in this research. Urease enzyme is manually mixed with additional $10 \%$ of clay soil to clay shale. The objective of mixing it is to increase the bearing capacity of the clay shale. Consolidated undrained triaxial test was performed for testing the soil strength performance for samples that had undergone curing for 2, 4, and 6 weeks. The results indicated that the sample stiffens, proved by the increase of shear strength from consolidated undrained triaxial test. The shear strength value produced by the variation of the urease enzyme mixture $+10 \%$ the clay is higher than that of without the original clay shale.
\end{abstract}

Keywords. stabilization, clay shale, urease enzyme, bio-cementation, consolidated undrained (cu), shear strength MSC. 65K10, 62P05, 94D05.

\section{Introduction}

The problems that often arises in the construction of buildings and roads are usually located in locations that have a layer of clay shale. Clay shale is one part of the problematic soils in the geotechnical field. One of the distinct characteristics of clay shale is if the coating conditions are covered with other soil layers and not disturbed, it has a large shear strength value similar to rocks. But, when the clay layer is exposed and come in contact with air and water, the layer will weathered. In nature, clay shale is formed due to the corrosion of claystone containing minerals such as Smectite, Kaolinite, and Illite [1]. These minerals causes the disintegration of clay shale which is categorized as physical disintegration whenever it comes in contact with air and water.

Clay shale is categorized in the mudstone section which has fissile texture [2]. In the Geological Engineering Map of Bogor, the characteristics of clay shale are compact but can be easily disintegrated, have well-lined layers, and low permeability [3].

There are some cases that happens due to the changes of shear strength of soil in Indonesia, one of which is the case of soil failure of Sports Center Facility in Hambalang, Bogor [4]. In the project, there was a slope stability failure that causes the failure of the structure of the building. The failure was caused by the surrounding layer that was classified as clay shale which was in the openair condition and had experienced weathering due to direct contact with air and water. Due to this case, there needs to be a significant research to anticipate similar problems caused by the properties of clay shale soil.

One of the improvement efforts that can be conducted on clay shale is soil stabilization method. The purpose of soil stabilization method is to increase the bearing capacity of certain soil. Generally, soil stabilization methods involve compacting and adding additive ingredients. Soil stabilization methods which involve additive ingredients usually use chemicals such as cement, limestone, and fly ash. As of now, these methods are still in use, but are deemed as not safe for the environment.
Due to the reasons stated above, in recent years, stabilization by utilizing biotechnology were introduced in the geotechnical field. Some of the examples are bio-grouting [5], bio-remediation [6], and bio-cementation [7] on sand and peat soils [8]. Results from the use of biotechnology such as bacteria and urease enzymes were proven to increase the bearing capacity of the soil. Usage of biotechnology as an option for stabilization is considered more sustainable, safe for the environment, and less expensive than using chemicals [9].

Urease enzyme is an enzyme produced by one of the oceanic bacteria depositing carbonates which is non-toxic and able to be a catalyst [10]. The enzyme catalyze urea to produce ammonia and carbon dioxide. Below is the chemical reaction for urea throughout the process:

Urea $+\mathrm{H}_{2} \mathrm{O} \stackrel{\text { Urease }}{\longrightarrow} \mathrm{CO}_{2}+2 \mathrm{NH}_{3}$

When urease is added into the medium, there will be an ammoniaforming reaction that increases the $\mathrm{pH}$ value of the medium. The higher $\mathrm{pH}$ medium will speed up the calcite precipitation process [11] as stated in the reaction below:

$$
\mathrm{Ca}^{2+}+2 \mathrm{HCO}_{3}{ }^{-} \rightarrow \mathrm{CaCO}_{3}+\mathrm{CO}_{2}+\mathrm{H}_{2} \mathrm{O}
$$

The objective of this study is to find significance from the effect of Urease Enzyme addition with and without clay soil on clay shale to its shear strength and friction angle with curing periods of 2,4 , and 6 weeks. 


\section{Methodology}

\subsection{Material, Stabilization Material and Types of Test- ing}

The sample for this research is clay shale soil taken from Sukamakmur District, Bogor Regency, West Java, whereas the clay soil was taken from Depok Regency, West Java. From specific gravity test, the specific gravity value for clay shale is 2.73 and clay is 2.69. The result of Hydrometer and Sieve Analysis test on clay and clay shale is shown in Figure 1. According to Unified Soil and Classification System (USCS), the clay shale can be classified as low plasticity clay, CL $(\mathrm{LL}=33.9 \%$ and $\mathrm{PI}=12.06 \%)$ whereas the clay soil is classified as high plasticity silt $(\mathrm{LL}=$ 92.98\% and PI $=46.62 \%$ ). From Unconfined Compression Test, the value of clay shale activity was 0.59 which can be categorized as inactive soil, whereas the clay soil activity value was 1.18 which can be categorized as soil with normal activity.

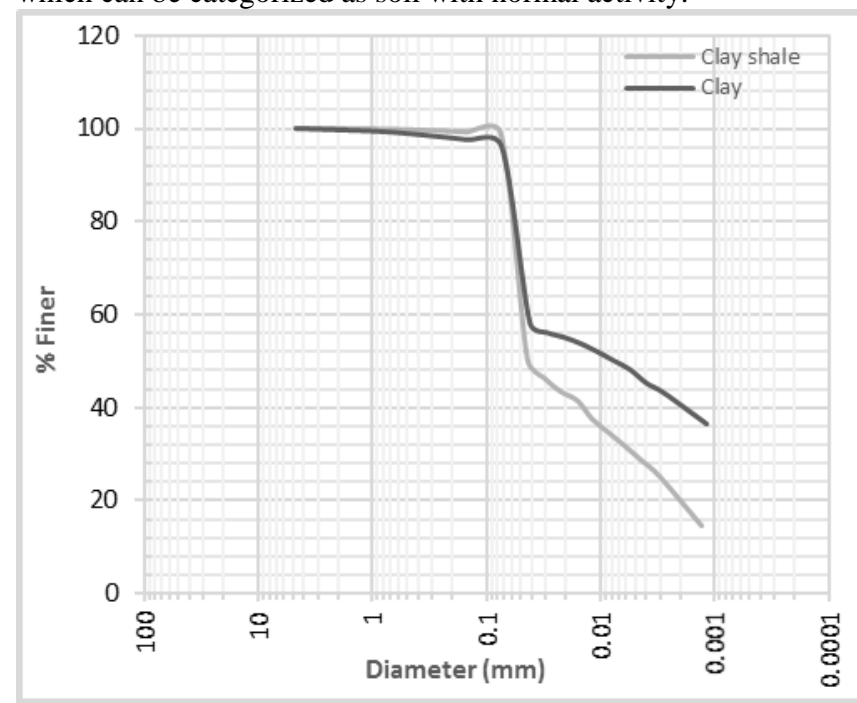

Figure 1. Grain curves of clays shale and the clay soil

The enzyme used in this study came from bacterium Oceanobacillus sp. P3BG43 which is isolated from lithosolic soil originating from Papua. The activity value for the urease enzyme is $194.04 \mathrm{U}$ $/ \mathrm{ml}$ and is ready to be mixed with the clay shale sample stated previously.

Index properties tests are conducted for the clay shale sample in several conditions such as original condition of the soil and soil condition after it is mixed with clay and urease enzyme. In addition, both of the results are compared and analyzed for its changes. Physical properties tests performed are specific gravity (SG) [ASTM D854-83], atterberg limit (ATL) (ASTM D4318-84), and sieve analysis (SA) (ASTM D422). Shear strength properties conducted for this research is triaxial Consolidated-Undrained (CU) (ASTM D4767) for samples with diameter $36 \mathrm{~mm}$. In order to gain more knowledge about the differences in the physical structure of clay shale in detail after adding microorganisms, a microscopic observation was performed in form of SEM (Scanning Electron Microscope) test.

The sample used in shear strength test is the disturbed condition. For this research, determining the shear strength properties uses the Consolidated Undrained (CU) Triaxial, resulting two parameters such as cohesion and friction angle.

\subsection{Biocementation of Urease Enzyme}

In this study, the volume of bio-cementation addition (enzyme and cementation solution) in clay shale was $10.76 \%$ from the soil volume in container and clay shale $+10 \%$ clay soil was $14.2 \%$. The numbers were based on the ability of clay shale and clay shale + $10 \%$ clay soil in accommodating liquid bio-cementation solution.
The calculation of enzyme concentration with cementation solution (Urea and $\mathrm{CaCl}_{2}$ ) was 1:4, whereas urea and $\mathrm{CaCl}_{2}$ had a ratio of $1: 2$ with each concentration of $1.1 \mathrm{M}$. The calculation of biocementation solution added to clay shale soil inside the container are presented in Table I.

Table I Calculation Of Enzyme Needs And Cementation Solutions

\begin{tabular}{|c|c|c|c|c|c|c|c|}
\hline \multirow{3}{*}{$\begin{array}{l}\mathbf{N} \\
\mathbf{0}\end{array}$} & \multirow{3}{*}{$\begin{array}{c}\text { Sam- } \\
\text { ple } \\
\text { Name }\end{array}$} & \multicolumn{3}{|c|}{ Dimension Mold } & \multicolumn{3}{|c|}{ Bio-cementation } \\
\hline & & \multirow[b]{2}{*}{$\underset{(\mathbf{c m})}{D}$} & \multirow{2}{*}{$\begin{array}{c}\text { h } \\
(\mathbf{c m})\end{array}$} & \multirow{2}{*}{$\begin{array}{c}\mathrm{V} \\
\left(\mathrm{cm}^{3}\right)\end{array}$} & \multirow{2}{*}{$\begin{array}{c}\text { En- } \\
\text { zyme } \\
(\mathbf{m L})\end{array}$} & \multicolumn{2}{|c|}{ Cementation } \\
\hline & & & & & & $\begin{array}{c}\text { Urea } \\
\text { (mL }\end{array}$ & $\begin{array}{c}\mathrm{CaCl}_{2} \\
(\mathrm{~mL})\end{array}$ \\
\hline 1 & $\begin{array}{l}\text { Clay } \\
\text { shale }\end{array}$ & $\begin{array}{l}15.2 \\
5\end{array}$ & $\begin{array}{l}11.6 \\
7\end{array}$ & $\begin{array}{l}2130.4 \\
9\end{array}$ & 45.85 & 91.69 & 91.69 \\
\hline 2 & $\begin{array}{l}\text { Clay } \\
\text { shale }+ \\
10 \% \\
\text { clay } \\
\text { soil }\end{array}$ & $\begin{array}{l}15.2 \\
5\end{array}$ & $\begin{array}{l}11.6 \\
7\end{array}$ & $\begin{array}{l}2130.4 \\
9\end{array}$ & 60.51 & $\begin{array}{l}121.0 \\
1\end{array}$ & $\begin{array}{l}121.0 \\
1\end{array}$ \\
\hline
\end{tabular}

Urease Enzyme is then mixed into both of the sample with manual mixing in order for the cementation to happen equally for the sample. Afterwards, the samples were then compacted in CBR Mold. Lastly, the samples should be left to settle for 2, 4, and six weeks. For the sample with 2 -week curing, the soil was molded into the triaxial mold. As for the 4-week and 6-week curing samples, bio-cementation solution was added as much of the solution in the beginning of the mixture using slow spray method on the surface of compacted sample.

The test sample mixed with the bio-cementation solution was stored in a place safe from physical disturbance. The top of the sample container was left open. Furthermore, the condition of test sample was kept moist and the sample temperature was saved in normal, room temperature $\left(28-30^{\circ} \mathrm{C}\right)$.

\subsection{Decomposition Analysis after the Addition of Ure- ase Enzyme}

Physically or visually, the most prominent difference in clay shale after it was mixed with urease enzyme and left to fermentation resulted as a more solid or hardened soil. There are several appearances of white dots on clay shale which indicated the formation of calcium carbonate in the inside. This happened due to the effect of mixing the clay with urease enzyme, functioning as a decomposition agent contained in clay shale.

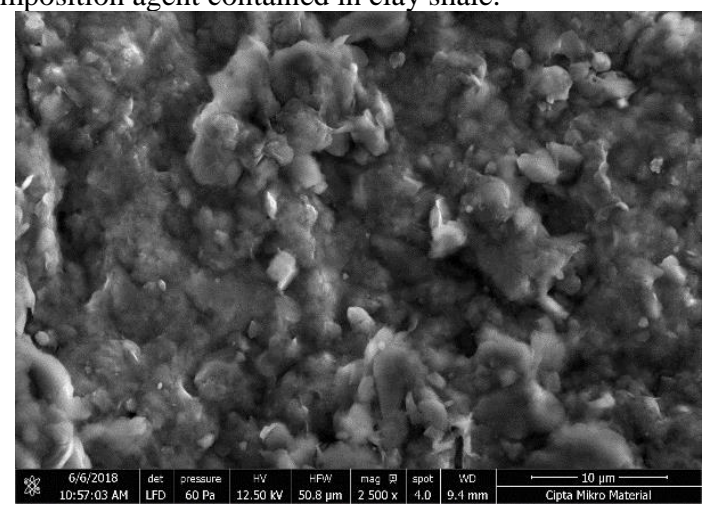

(a) 


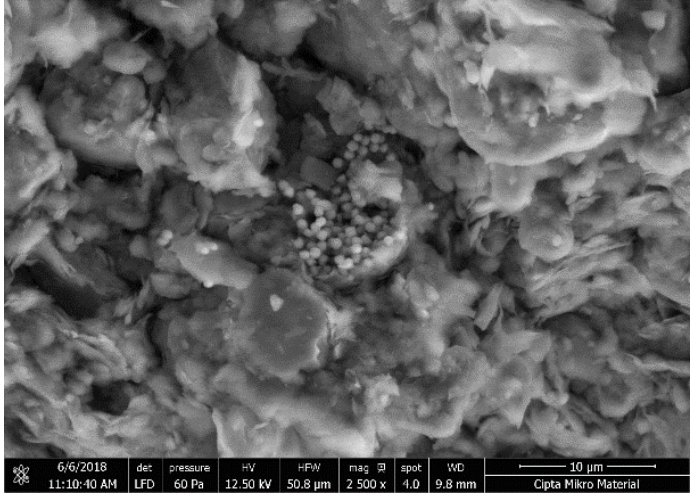

(b)

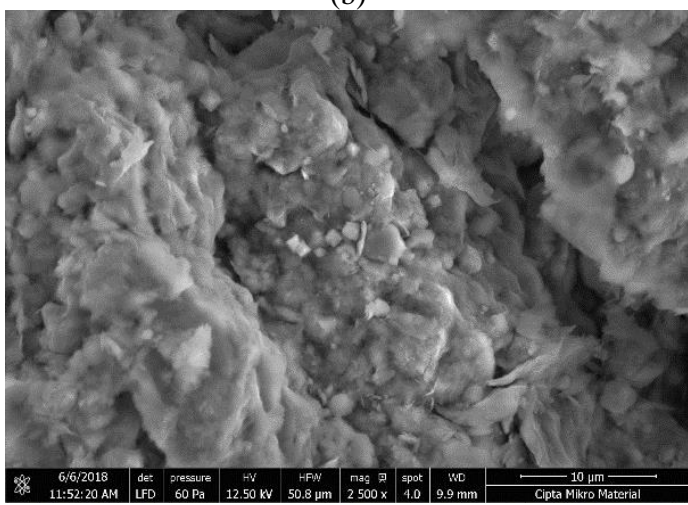

(c)

Figure 2. Micrograph SEM magnification 2500 times; (a) Clay shale; (b) Clay shale after the addition of urease enzyme; (c) Clay shale $+10 \%$ Clay soil after the addition of urease enzyme

The purpose of adding urease enzyme to clay shale was to make the decomposition process occurred which means that decomposing clay shale with porosity available for the sample will make it denser and compact. To gain more insights about the detail physical structure distinctions of clay shale soil after the addition of urease enzyme, microscopic observation was conducted by SEM micrograph. In Figure 2 (a), it can be seen that the particles on clay shale were not bounded.

Moreover, between aggregations, there were cavity or double pores, namely trans and inter assemblage pores. When the original clay shale topography was enlarged, the microscopic fibers and pores between clay shale soil particles were clearly observed. This is called the double fiber of original clay shale soil. Then, after 6 weeks of curing (Fig. 2 (b)), the establishment of calcium carbonate minerals; still not fully formed by the urease enzyme, became much dense and compact particles.

\subsection{The change of Shear Strength parameters after ad- dition of urease enzyme}

The shear strength resulted from the consolidated undrained triaxial test is carried out in three stages:

\section{Saturation Stage}

At the saturation stage a variation in the degree of saturation rating will be given. Using formula $a_{s}$. To achieve the ideal saturation degree, the value must be at least 0.95 for the sample to be saturated. In order to achieve this value, three stages of cell pressure are needed consisting of 50,100, and $150 \mathrm{kPa}$. These values are needed in order to reach $\sigma_{3}$ given to each sample.

\section{Consolidation Stage}

The next stage after the saturation stage is the consolidation stage. This consolidation stage provides effective stresses on the original soil samples as well as the mixtures tested in accordance with the actual effective stresses in the field. Knowing the volume change that occur after the sample is given a certain stress until pore water were drained out from the sample. The effective stresses given in this test are $100 \mathrm{kPa}, 200 \mathrm{kPa}$ and $300 \mathrm{kPa}$.

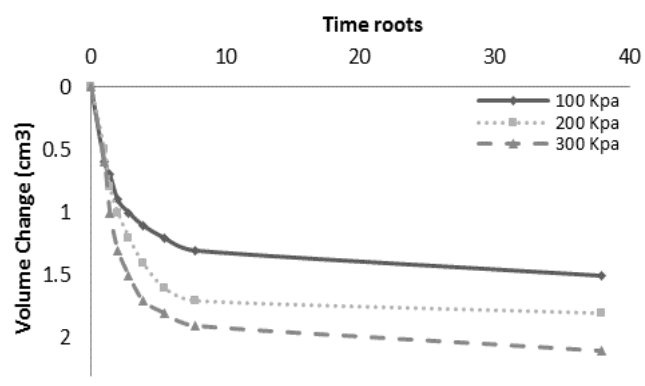

Figure 3. Graph of volume change to Clay Shale root of 0 weeks

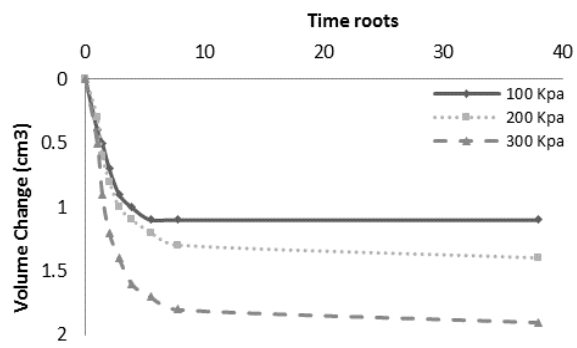

Figure 4. Graph of volume change to Clay Shale $+10 \%$ clay soil + enzyme root of 6 weeks

The drainage pattern of the three samples are similar when the root of time approaches the value 10 . When it reaches the root of time 10, all samples experience an almost stable volume change. By $300 \mathrm{kPa}$ pressure, the volume change achieved by the clay shale sample reaches $2.1 \mathrm{~cm}^{3}$ (Figure 3 ). Whereas the clay shale mixed with $10 \%$ clay sample only reaches $1.9 \mathrm{~cm}^{3}$ (Figure 4). This behavior indicates that the inter-pore cavities reduces by time due to formation of $\mathrm{CaCO}_{3}$.

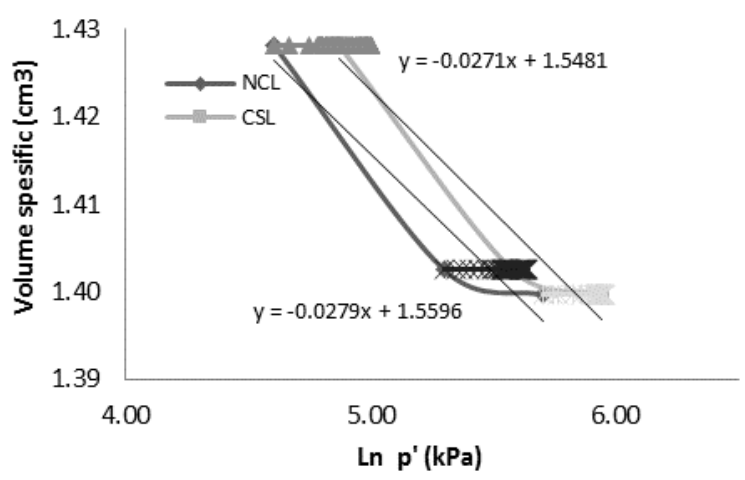

Figure 5. Graph of the relationship between specific volume with Ln p' Clay shale 0 week

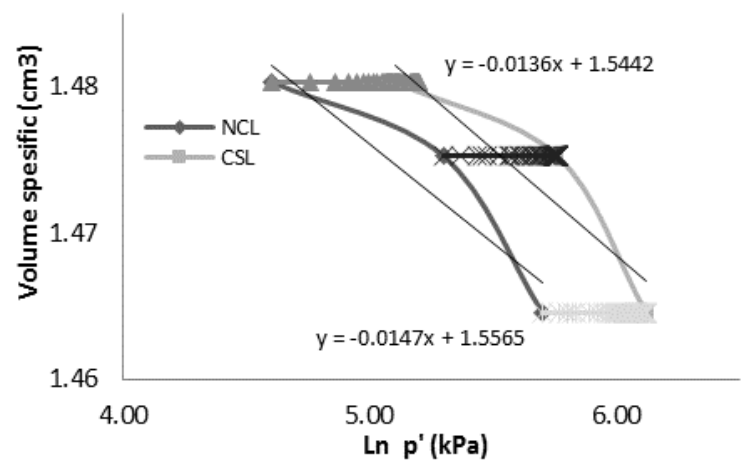

Figure 6. Graph of the relationship between specific volume with Ln $\mathrm{p}^{\prime}$ Clay shale $+10 \%$ clay soil + enzyme 6 weeks

From Figure 5 and Figure 6 above, it can be seen that the CSL line 
is at the right side of NSL line. This happens because the sample is over-consolidated. Both the clay shale sample without undergoing curing and clay shale sample with $10 \%$ clay and enzyme undergoing 6-weeks of curing exhibits a movement of the specific volume graph direction from the left to right due to the increasing effective stress given to the sample which is coherent with the increasing compression process. The specific volume of the samples decreases from 1.43 to 1.40 for clay shale samples, whereas the specific volume in clay shale sample $+10 \%$ clay + enzyme with 6 weeks of curing period decreases from 1.48 to 1.46 .

\section{Compression Stage}

The last stage of the CU triaxial test is the compression stage. At this stage, the sample is applied to pressure until the sample collapse or fail, which is marked with the decrease or stagnant reading value from the load dial. The analyses taken into account for this test is Stress Path Method.

\subsection{Samples of clay shale without curing}

From Figure 7 below, the result shows the stress path produced from the maximum deviator stress value in each given stress condition. The result can be plotted as a stress path line equation of $y$ $=1.06 x+51.34$. Furthermore, the equation of the line generates the value of failure criterions ( $\mathrm{M}$ and $\mathrm{q}_{0}$ ).

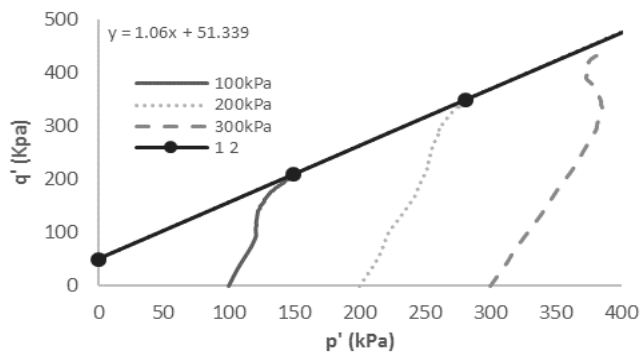

Figure 7. Effective stress change graph (p') to Deviator Stress ( $\left.\mathrm{q}^{\prime}\right)$ clay shale 0 week

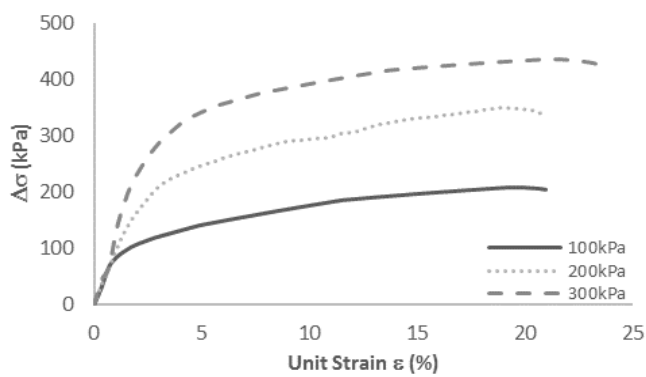

Figure 8. Graph of Strain Unit $(\varepsilon)$ Against Deviator Stress $(\Delta \sigma)$ clay shale 0 week

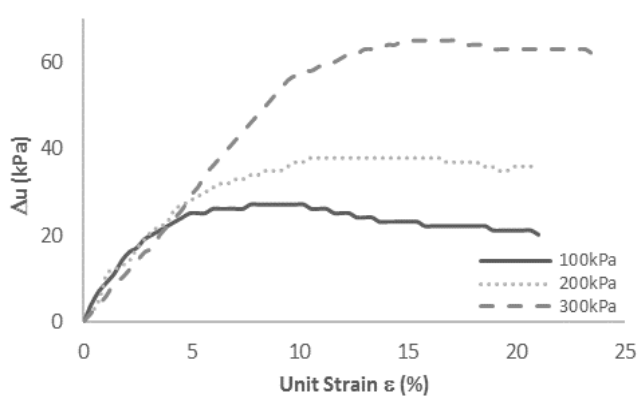

Figure 9. Graph of strain unit $(\varepsilon)$ to changes in pore pressure $(\Delta \mathrm{u})$ of clay shale 0 week

It can be seen in Figure 8 that the deviator stress will increase along with the increase of given stress and consolidation stress. The maximum point is reached on the graph at $435.18 \mathrm{kPa}$ with the unit strain of $21.03 \%$. The curve shows that afterwards, the deviator stress decreases with the increase of unit strain.

From Figure 9, it can be inferred that change of pore water pressure decreases with the increase of unit strain. This is due to the soil condition where the water content decreases with the increasing time of curing period. By the time of the test, the change of pore water pressure in the soil sample will also decrease due to this reason. In non-drained conditions, water is not allowed to flow out, which indicates that pore water pressure also hold the given load applied to the soil sample. In this case, when the given load increases, the pore water pressure will also increase. The maximum pore water pressure is reached at the value of $63 \mathrm{kPa}$ with unit strain value of $21.03 \%$.

\subsection{Clay shale sample $+10 \%$ clay + enzyme with 6 weeks curing period}

From Figure 10 below, the result shows the stress path produced from the maximum deviator stress value in each given stress condition. The result can be plotted as a stress path line equation of $y$ $=1.10 x+111.42$. Furthermore, the equation of the line generates the value of failure criterions ( $\mathrm{M}$ and $\mathrm{q}_{0}$ ) after the sample was added with $10 \%$ clays and enzymes.

From Figure 11, it can be seen that the deviator stress will increase along with the increase of given stress and consolidation stress. The maximum point is reached on the graph at $621.25 \mathrm{kPa}$ with the unit strain of $20.6 \%$.

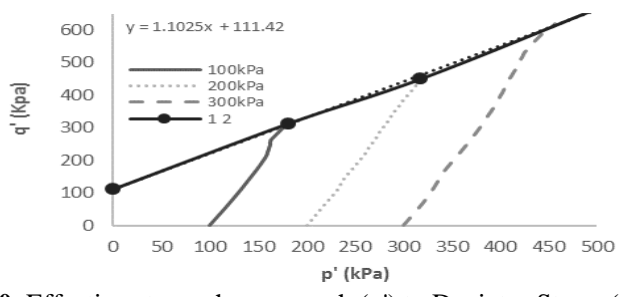

Figure 10. Effective stress change graph $\left(\mathrm{p}^{\prime}\right)$ to Deviator Stress $\left(\mathrm{q}^{\prime}\right)$ clay shale $+10 \%$ clay soil + enzyme 6 week

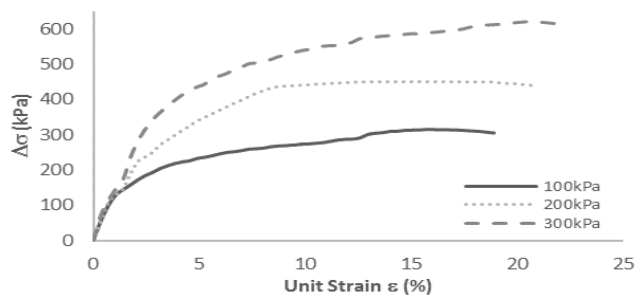

Figure 11. Graph of Strain Unit $(\varepsilon)$ Against Deviator Stress $(\Delta \sigma)$ clay shale $+10 \%$ clay soil + enzyme 6 weeks

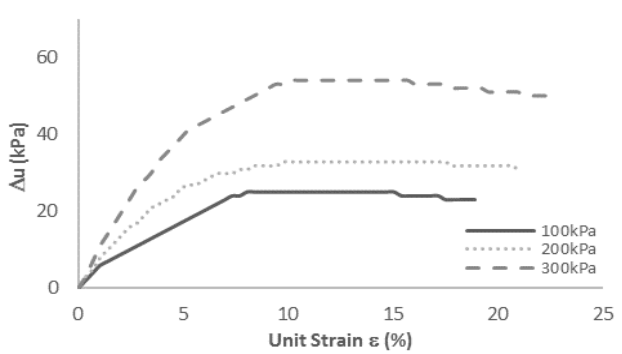

Figure 12. Graph of strain unit $(\varepsilon)$ to changes in pore pressure $(\Delta u)$ of clay shale $+10 \%$ clay soil + enzyme 6 weeks

From Figure 12, it can be inferred that change of pore water pressure decreases with the increase of unit strain. This is due to the soil condition where the water content decreases with the increasing time of curing period. By the time of the test, the change of pore water pressure in the soil sample will also decrease due to this reason. The maximum pore water pressure is reached at the value of $51 \mathrm{kPa}$ with unit strain value of $20.6 \%$. This condition indicates that the pores in clay mixture sample is smaller than the 
original clay shale sample due to the formation of granule particles by $\mathrm{CaCO}_{3}$.

Referring to the Mohr - Coulomb theory by [12] to see the shear strength of the soil obtained from the parameters in this test, the equation is as follow:

$\theta=45^{\circ}+\Phi^{\theta} / 2$

$\sigma_{f}^{s}=\frac{1}{2}\left(\sigma_{1}^{s}+\sigma_{a}^{s}\right)+\frac{1}{2}\left(\sigma_{1}^{s}-\sigma_{a}^{s}\right) \cos 2 \theta$

$\tau_{f}=\frac{1}{2}\left(\sigma^{s}{ }_{1}-\sigma^{\theta}{ }_{\mathrm{a}}\right) \sin 2 \theta$

In order to see the magnitude of the increase in soil shear strength of a series of Triaxial CU tests, the equations (3), (4), and (5) are used. The results for the calculations according to the values obtained from the test can be seen in Table II.

The results have proven that longer curing time of will result in a larger cohesion value, but will not significantly change the friction angle. This indicates that the sample has not undergone a complete process of $\mathrm{CaCO}_{3}$ formation nor does it spreads throughout the sample yet, resulting to insignificant increase of the friction angle.

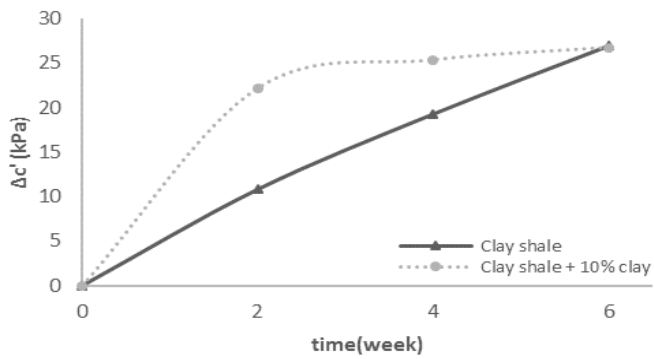

Figure 13. Graph of effective cohesion change $\left(\Delta c^{\prime}\right)$ against curing time

From Figure 13 and the results in Table II, it can be inferred that from the eight variation of samples, the effective curing time for the clay shale $+10 \%$ clay + enzyme sample is 4 weeks. This is due to the cohesion change $\left(\Delta c^{\prime}\right)$ that increases from the initial state until 4-week, but remains stagnant afterwards. As for the clay shale sample which is mixed with enzyme, the value keeps increasing even after 6-weeks.

Table II Shear strength parameters the original soil and mixed soil + enzyme

\begin{tabular}{|c|c|c|c|c|}
\hline \multirow[b]{2}{*}{ Sample } & $\phi^{\prime}$ & $\mathbf{C}^{\prime}$ & $\Sigma^{\prime} \mathbf{f}$ & Tf \\
\hline & $\begin{array}{l}\text { (De } \\
\text { g) }\end{array}$ & $\begin{array}{c}\text { (Kp } \\
\text { a) }\end{array}$ & $\begin{array}{c}(\mathbf{K g} / \mathbf{C m} \\
2) \\
\end{array}$ & $\begin{array}{c}(\mathrm{Kg} / \mathrm{Cm} \\
2) \\
\end{array}$ \\
\hline Clay Shale 0 Week & $\begin{array}{c}26.7 \\
7\end{array}$ & $\begin{array}{c}23.3 \\
6\end{array}$ & 1.36 & 0.93 \\
\hline Clay Shale + Enzyme 2 Weeks & $\begin{array}{c}26.5 \\
4 \\
\end{array}$ & $\begin{array}{c}34.1 \\
8\end{array}$ & 1.53 & 1.12 \\
\hline Clay Shale + Enzyme 4 Weeks & $\begin{array}{c}26.3 \\
1\end{array}$ & $\begin{array}{c}42.6 \\
4\end{array}$ & 1.51 & 1.19 \\
\hline Clay Shale + Enzyme 6 Weeks & $\begin{array}{c}27.2 \\
3\end{array}$ & $\begin{array}{c}50.3 \\
2\end{array}$ & 1.57 & 1.33 \\
\hline $\begin{array}{r}\text { Clay Shale }+10 \% \text { Clay Soil } 0 \\
\text { Week }\end{array}$ & $\begin{array}{c}25.0 \\
5 \\
\end{array}$ & $\begin{array}{c}24.1 \\
7 \\
\end{array}$ & 1.53 & 0.96 \\
\hline $\begin{array}{r}\text { Clay Shale }+10 \% \text { Clay Soil }+ \\
\text { Enzyme } \\
2 \text { Weeks }\end{array}$ & $\begin{array}{c}26.0 \\
7\end{array}$ & $\begin{array}{c}46.3 \\
6\end{array}$ & 1.41 & 1.19 \\
\hline $\begin{array}{r}\text { Clay Shale }+10 \% \text { Clay Soil + } \\
\text { Enzyme } \\
4 \text { Weeks } \\
\end{array}$ & $\begin{array}{c}26.3 \\
1\end{array}$ & $\begin{array}{c}49.5 \\
4\end{array}$ & 1.58 & 1.31 \\
\hline $\begin{array}{r}\text { Clay Shale }+10 \% \text { Clay Soil }+ \\
\text { Enzyme } \\
6 \text { Weeks }\end{array}$ & $\begin{array}{c}27.7 \\
0\end{array}$ & $\begin{array}{c}50.9 \\
3\end{array}$ & 1.60 & 1.39 \\
\hline
\end{tabular}

From the test for original clay shale sample, it can be known that the cohesion (c) is $23.36 \mathrm{kPa}$ and the friction angle $(\varphi)$ is $26.77^{\circ}$. On the other hand, the results for clay shale with addition of $10 \%$ clay and enzyme obtained from the same test are $50.93 \mathrm{kPa}$ for the cohesion (c) and $27.70^{\circ}$ for the friction angle $(\varphi)$.

\section{Results and Suggestion}

It can be concluded from this study that usage of enzyme and cementation solutions are able to produce biocementation for clay shale. Biocementation formation increases the cohesion value until two times, about $218 \%$, from the original state of the clay shale. However, further research is needed to obtain a more optimal portion of the solution also relating it to the weathering properties of clay shale.

Adding $10 \%$ clays and urease enzymes has also proven to improve shear strength parameters, where it increases the effective cohesion (c'), yet not significantly changes the effective friction angle $\left(\varphi^{\prime}\right)$. The results indicate that there needs to be improvement on the type and portion of the clays which will be added to clay shale. In addition, the clay should have low activity value and low to medium plasticity to improve the main characteristic of the clay shale.

\section{References}

[1] I. M. Alatas and P. T. Simatupang, "Pengaruh proses pelapukan clay shale terhadap perubahan parameter rasio disintegritas (DR)," vol.24, no.1, pp. 77-82, April 2017.

[2] D. A. V. Stow, " Fine-grained sediments: terminology," Q. J. eng. Geol. London, vol. 14, pp. 243-244, 1981.

[3] T. Tobing, and A. Luthfi, "Engineering Geologic Map of Bogor Quadrangle, West Java 1209-1, scale 1:100.000," Directorate Enviromental Geology , Bandung, 1995.

[4] I. A. Sadisun, R. D. Kartiko, A. Kesumaningtyas, T. E. Utami, and E. Sucipta, "Shear strength reduction of tertiary jatiluhur- subang claystones due to swelling processes," Proceeding of 10th Asian Regional Conference of IAEG Japan, pp. 1-4, Sept 2015.

[5] T. Harianto, S. Hamzah, S. H. Nur, M. A. Abdurrahman, R. U. Latief, I. Fadliah, A. Walenna, "Biogrouting stabilization on marine sandy clay soil." Proceedings of the 7th International Conference on Asian and Pacific Coasts (APAC 2013) Bali, 2013.

[6] Y. Fujita, F. G. Ferris, R. D. Lawson, F. S. Colwell, R. W. Smith, "Calcium carbonate precipitation by ureolytic subsurface bacteria". Geomicrobiol Journal, vo.17, pp. 305-318, Jan 2000.

[7] Y. H. Suprapto, "Application Of Microbiology To Improve Mechanical Properties Of Soil And Concrete". Tesis Universite Lille1, Lille, 2011.

[8] W. Rahayu, P. Lisdiyanti, R. E. Pratama, "Tanah gambut melalui uji triaksial consolidated undrained dan unconsolidated undrained, vol.22, no.3, pp. 201-208, Dec 2015.

[9] Ivanov, Volodimir \& Stabnikov, Viktor, "Construction biotechnology: biogeochemsitry, microbiology, and biotechnology of construction materials and processes". Singapore: Springer, 2017.

[10] S. Aininyah, P. E. Nugroho, P. Lisdiyanti, M. P. Koentjoro, "Biogrouting: produksi urease dari bakteri laut (Oceanobaccillus sp.) pengendap karbonat, Jurnal Sains dan Seni POMITS, vol. 2, no.1, Sept 2014.

[11] I. A. Sadisun, R. D. Kartiko, A. Kesumaningtyas, T. E. Utami, dan E. Sucipta, "Shear Strength Reduction of Tertiary Jatiluhur- Subang Claystones Due to Swelling Processes," no. SEPTEMBER 2015, hal. $1-4,2016$.

[12] P. Lisdiyanti, "Biogrouting : Pemanfaatan Mikroba Laut Pengendap Karbonat Dalam Penanganan Erosi Pantai". Bogor, 2012.

[13] R. F. Craig, "Soil Mechanics, Fourth Edition. UK: Van Nostroad Reinhold Co. Ltd, pp.93, 2004 